\title{
Multiculturalism in the Local Wisdom of Bajo Tribe
}

\author{
La Ode Ali Basri ${ }^{1}$ \\ ${ }^{1}$ Department of History, Faculty of Cultural Science, Universitas Halu Oleo Kendari, Indonesia \\ Correspondent: La Ode Ali Basri, Department of History, Faculty of Cultural Science, Universitas Halu Oleo \\ Kendari, Indonesia. E-mail: basri.uho74@gmail.com
}

Received: November 11, 2017

Accepted: December 21, 2016

Online Published: January 15, 2018

doi:10.5539/ach.v10n1p71

URL: http://dx.doi.org/10.5539/ach.v10n1p71

\begin{abstract}
This research reveals multiculturalism contained in the oral tradition of the Bajo tribe. The results showed that multiculturalism in Bajo tradition is as follows; 1) ethical philosophy of the Bajosnamely tahangdiri (self-control) and ngatonang diri (self-awareness). Tahang diri is the ethical concept of behaving of Bajo tribe that in their life, they must refrain from misbehavior. Ngatonang diri implies that every individual should be aware of all the weaknesses and the strengths they belong. Bajoprincipally are ordinary people who cannot survive without the helpfrom other people, the sea and the Ruler of the sea; 2) the tradition of pamali (taboos), for instance pamali making the neighbors annoy by throwing the clamshells into their boat and throwing the sand in their yard and pamali killing the animals such as pig, jonga (deer) and other land animals that descend into the sea; 3 ) the problem solving tradition of Bajo through the arbitration system in which if there is a conflict among the people, there should be third person (mediator) to take an action in solving the problem.
\end{abstract}

Keywords: Local wisdom, multiculturalism, and Bajo tribe

\section{Introduction}

Each group of society has their own traditional culture and local wisdom which become characteristic and uniqueness of their community (Basri et al., 2017). In the middle of a crisis of values of today's modern culture, traditional culture exists as a subject of study of various circles, as it is believed that the traditional culture contains a number of local wisdom, which can be a solution to the crisis of modern culture (Herman, 2016). One of the wisdoms covered in the traditional culture is belief which recognizes the differences in diversity and glorifies differences and diversity in equality. The plurality and heterogeneity is an inevitability as a consequence of the diversity of cultural, ethnic and religious sects (Naim et al., 2008). According Mungmachon (2012) multiculturalism in local culture comes from life experiences and the results of local people's interaction with their natural surroundings.

In the science perspective,the belief and the judgment that give rise to an attitude of respect and curiosity to other ethnic cultures is called multiculturalism, that is an ideology that recognizes and glorifies differences in equality, both individually and collectively (Fay, 2006). Multiculturalism is acomplexity of ideas, perspectives, policy, attitude and action, by a person or group of people which is diverse in terms of ethnic, culture, religion and so on, but the individual or group of individuals aspires to increase the spirit of diversity and have the pride to maintain the diversity or the right of plurality (Lubis, 2006). Meanwhile, Banks (2007) argues that multilkultural is a principle of mutual culture and mutual respect among all cultural groups in society to realize ideal democratic life. In addition, multiculturalism is believed to be a real solution to conflict and disharmony that occurs in society as a result of plurality and plurality of people (Pettalongi, 2013).

The concept of multiculturalism, indeed, had been taught by the ancestor of each group of society in this world that conveyed orally from one generation to the next. This is evident the some of the results of studies about the multiculturalism in the traditional cultures by, among others, Yeh et al. (2005) to the young Korean immigrant. The study showed that the young Korean implement norms and values of Korean culture to address the changing of identity and cultural acculturation, especially with the American culture. Another study was also carried out by Chen (2015) and it was about the Aborigines in Taiwan, the results showed that social experiences with other Aboriginal group members and learn about traditional tribal cultures create a more positive ethnic identity.

In addition, through international performances, they get self-confidence and diverse perspective. On the other hand, Clark et al. (2002) stated that multiculturalism can serve as a bridge to the socio-economic gab of students in 
accessing digital world, forming the sensitivity of students towards the environment and they can work together although they have different socio-economic backgrounds. This is what Convertino (2016) means, that multiculturalism allows for dialogue and sharing knowledge. According to Mungmachon (2012) such multicultural understanding is formed from local community life experience in interacting with others and the results of the local community interaction with their natural surroundings.

The findings of the above studies further confirm that within the local culture, there is a number of wisdoms that appreciatethe plurality, including in the traditional culture of the Bajocommunity in Southeast Sulawesi. Bajo community has a set of local wisdom stored in its social and cultural system (Basri et al., 2017). The wisdom is among others found in oral tradition, which has been legacy of Bajo people. The Bajos has oral traditions that contain a concept of how to deal with differences by promoting toleranceand egalitarian spirit, as well as the conception of the ordinances of appreciate and celebrate diversity in equality. Therefore, this paper attempts to explore the oral tradition of the Bajos which is believed that it has relevance to the concept of multiculturalism for the harmonization of sustainable human life.

\section{Research Methods}

The research was conducted in Bungin Village of Tinanggea District, South Konawe Regency, Southeast Sulawesi. The informant in this study were the socialites/community leaders that consist of eliteelders, youth leaders, and other people who have power in the community. The samples were determined purposively. The data was collected through: (1) participant observation; the researcher was directly involved in the activities of the informants that have relevance to the focus of the study, as well as to directly observe the activity of the Bajo people; (2) conducting in-depth interviews to the informants, particularly community leaders, both religious leaders, tradition leaders, youth leaders and other Bajos for about the ideas, experience, knowledge of the informant about various matters relating to the oral tradition of the Bajos; (3) conducting a literature study which links to the local culture of Bajo.

After the data were collected, they were then analyzed through descriptive-qualitative design based on the models of Milles and Huberman (1991) by using the following steps; (1) data reduction, arranged the units of entire data collected from interviews, observation, literature study and focused discussion. The data was selected one by one, classified based on its group, and then performed reduction data to eliminate less relevant data, made transliteration and abstraction and also arranged data units. (2) data presentation, conducted a data categorization, developed the connection between categories, compared one category of data with other categories, and interpreted the meanings of each relationships of the data; and (3) conclusion, provided interpretation and the connection between categories of data which had been already organized to discovered the meaning and their conclusions.

\section{Results and Discussion}

\subsection{Multiculturalism in Bajo's Ethical Philosophy}

The Bajo tribe have moral teachings that contain values of multicultural. The moral teachings are tahang diri (self-control) ngatonang diri (self- awareness). Tahang diri (self- control) is a moral teaching of the Bajo which implies that in their life, they must refrain from misbehavior. For example, in making a living, the Bajo should not be greedy, they should not take the rights of others, and they should not justify all means, even to damage the relationship with other human beings, with the marine environment and with MboMa'di Lao (God of the Sea). As a place to earn a living, the sea must always be preserved and maintained, because the sea is not only as a primary source of life, but it also as the future of their children and grandchildren. The Bajo people express their appreciation to the sea through the traditional motto "kadampa annu kampo maiga-iga, pugai Allou mabunda ana'umputa". (Love the marine environment for the future of our children and grandchildren).

Ngatonang diri (self awareness) implies that every individual should be aware of all the weaknesses and strengths that exist in every individual. Bajos principally is ordinary people who cannot survive without the help from other people, the sea and Mbo Ma'dilao (God of the Sea). Therefore, each individual must maintain good relationships with other human beings, with God and with the natural environment including all creatures in it. With other human beings ingeneral, and with Bajo fellows specifically, they have to respect, and trust each other (Basri, 2010).

The belief about ngatonan gdiri and tahang diri is always engraved on the Bajo people's mind, and they are invested or handed down orally by the older generation to the younger Bajo generation. In the view of Bajo people, the principles of humane attitude towards fellow human beings have been taught by their ancestors for their generations. These principles are sippatappa (trust each other), sikaada (accept each other) and help each other or situlutulu. . Bajo awareness about the collective life creates asocial piety that changes individual behavior into social behavior; so as to create an orderly interrelation process between individuals in that collective life (Basri et al., 2011). 


\subsection{Multiculturalism in Pamali (Taboo) of Bajo}

One of the moral teachings in the social life of the Bajo is pemali to make neighbors irritated. These kind of principlecan be observed in the belief of Bajo that it is a taboo when offending the neighbors by throwing clams hells into their boats and throwing sand in their yards. According to the Bajo people, the philosophy above implies the need to maintain the integrity of the community, and the integrity of the community depends on the manners and characters. The words "do not annoy the neighbors by throwing clams hells into their boats and throwing sand in their yards", hinting that the clamshells were rough, prickly and sharp. If it is stepped on it can cause leg injury, or make feelings discomfort if someone sat on it, while the boat is a symbol of life of Bajo. For thatreason, Bajo should not hurt someone's feelings, envy and jealous each other.

Meanwhile, the home floor is as the tall as the series of board and road which has the function to make close from one home to another home. This is the reason why ethics and moral philosophy of Bajo teaches people to keep neighbors' feelings by not spreading or putting the sand in someone's yard. It is because the grains of sand are elements that are easily flown by the wind and if they get into the house, it will certainly contaminate the house and furniture so that it can disturb the comfort of the inhabitants of the house that can even interfere with the process of procreation in the household. Therefore, the attitude that must be grown in the neighboring life is that each individual should fully practice attitude of open mind, appreciate differences of views, understand each other, increase patience, exchange opinions, find common ground and tighten relationship with wisdom and love.

The Bajo is one of communities who always live peacefully and happily on the sea. There is no dispute and hostility among them. According to the Bajo, animals should not be killed or disturbed, nor human beings. The taboo to kill animals can be observed at pamali of Bajo in banning to kill a pig or deer which happen to descend on the sea. The Bajo believes that Mbo ma 'Lao has a good relationship with the God of mainland, so they should be able to refrain from killing pig, deer or other land animals that go down to the sea. Because they think the animals might be an incarnation of Mbo ma dara (God of the land). This is in line with the results of Zacot's study (2008) which shows that the Bajo people do not only have pamali about the sea but they also have a number of abstinences relating to life on land. According to Zakot, the taboos affect in herently the lives of Bajo thoroughly. Meanwhile, Pranowo (1998), Taena at al. (2016) states that the pemali or in the tradition of abstinence banned which became one of the views and guidance of life of a society that became controller for a person (self control) and for society collectively (social control).

Pamali existing in Bajo community is a controller for all Bajo peoplecollectively in order not to have bad temper, not to do anything that is against the law, not violate the norms of ethics and morality, and not damage the environment, respecting and exalting the differences in equality. Pamali also deals with the safety of individuals and Bajo society in general, because the Bajo people believe in pamali as karma law, if it is violated its karma will happen to those who violate it or its family and offspring anytime and anywhere (Basri et al., 2017). Thus the concept of pamali of Bajo is a manifestation of universal values of humanity which consistent with the basic principles of multiculturalism.

\subsection{Multiculturalism in Conflict Resolution of Bajo}

There is a story of the life history of Bajo that once upon a time there were child siblings involved in quarrel. In that incident, one came to reconcile them, and finally the two children reconciled and forgave each other. In addition, there is also a story of a man who is at loggerheadwith his father in-laws, then came someone who act as a mediator to reconcile them. The mediator came to one of them by saying that the other felt sad and wanted to make peace. Ultimately peace between the son in-law and the father in-law can be realized.

That is the Bajo, they have management of conflict resolution which is inherited from their ancestors to realize the social order in people life. Every time in mediating the conflict the elders (tradition elites) always give understanding to the warring people that in the past, when their descendants had a conflict or misunderstanding among them, one of them used to would gave in. They expressed feelings of guilty to others who are considered to be mediators to tell their opponents about their guilty and needed to make peace. At the level of social praxis, this conflict resolution has proven to be able to create harmony and peace in theBajo community.

Harmony is the main pillar in affirming Bajo community, so that all forms of disputes and misunderstandings can be avoided. If two people have a misunderstanding, then the third person acts to reconcile. It is a Bajo tradition that elders are fully responsible for reconciling a conflict. If there is a quarrel, the third person, in this cases, the elders will come continually to advise that anger and bad-tempered are the work of devil. If someone is not able to control emotions or a sense of anger, it is a sign that the person is being invaded by Setan (Evil). On the occasion, the third person also told one of them that the other felt sad and wanted to make peace. And so on until both sides are at peace. 
Dambarisan spirit (unity) and the brotherhood of the Bajo is extremely importance that Zacot (2008) calls Bajo as a peace-loving community, people who do not like to grumble. According to Zacot (2008) Bajo people do not like cruelty. They prove it in everyday life. People feel their self-esteem will fall when they get angry. Beside some quarrels between husband and wife that are easily heard through the partition wall, there are no more other quarrels we find among the people of Bajo. This is the same with the view of Jati (2013) that local wisdom has an important role in reconciliation by bringing community solidarity that have been in conflict.

Observing fragments of the oral tradition of the Bajo as described above, it vividly appear that in the oral tradition there are universal values of humanity which consistent with the concept of multiculturalism that can be used as a guideline in the effort to create a better civilized and humane life in the frame of diversity of cultural, ethnic and religious.

\section{Conclusion}

Multiculturalism in the Bajo's traditional culture among others, can be found in the oral tradition as follows.

Ethical philosophy of Bajo tribe namely tahang diri (self-control)and ngatonang diri (self-awareness). Tahang diri is ethical concept of Bajo that in running the life process in the world, Bajo should refrain from deviation behaviors. Ngatonang diri implies that every individual should be aware of all the weaknesses and the strength they belong. Bajo, principally are ordinary people who cannot stand alone without the help of others, the sea and the sea God.

Tradition pamali (taboo), among others, pamali to annoy the neighbors by throwing clams hells into the boat and throwing sand in their yard and pomaali to kill land animals such as pig, jonga (deer) and other land animals that go down to the sea.

The Problem solving of Bajois a model of conflict resolution through arbitration system thatif there are people get into a conflict, there must be a third person doing reconciliation (mediator).

\section{References}

Basri, A. O. L. (2010). Pemanfaatan Kearifan Lokal Sebagai Modal Sosial Budaya Dalam Pemberdayaan Masyarakat Pesisir Etnik Bajo.

Basri, A. O. L., Mudana, I. W., Habsah, W. O. S., Marhadi, A., Tarifu, L., Burhan, F., \& Janu, L. (2017). Pamali, Bajo's Local Wisdom in the Conservation of Marine Resources. Asian Social Science, 13(12), 63-67.

Basri, A. O. L., Momo, A. H., Mudana, I. W., Taena, L., Salniwati, S., Janu, L., \& Aswati, A. (2017). The Values of Multicultural Education in Munanese Traditional Culture. Asian Culture and History, 9(1), 33-39.

Basri, A. O. L., Mudana, I. W., \& Rahman, A. (2017). The Negative Stigma Against the Bajo Tribe and its Impact on Local Culture: Study of the Bajo Tribe in Bungin Village of South Konawe. Asian Culture and History, 9(2), 90-95.

Ali Basri, L. O., Parimartha, I., Ardika, I. W., \& Meko Mbete, A. (2012). Local genius as socio-cultural capital for empowering the bajo ethnic people residing at the coastal area of bungin permai village, south east sulawesi. E-Journal of Cultural Studies, 5(1).

Banks, J. A. (2007). Educating citizens in a multicultural society. New York: Teachers College Columbia University.

Basri, A., \& Ode, L. (2010), Pemanfaatan Kearifan Lokal Sebagai Modal Sosial Budaya Dalam Pemberdayaan Masyarakat Pesisir Etnik Bajo. Disertasi. Udayana: Denpasar.

Chen, S. M., \& Lee, Y. A. (2015). Dancing with Ethnic Identities: An Aboriginal Dance Club in a Taiwanese Middle School. International Journal of Multicultural Education, 17(2), 20-35.

Clark, C., \& Gorski, P. (2002). Multicultural education and the digital divide: Focus on socioeconomic class background. Multicultural Perspectives, 4(3), 25-36.

Convertino, C. (2016). Beyond Ethnic Tidbits: Toward a Critical and Dialogical Model in Multicultural Social Justice Teacher Preparation. International Journal of Multicultural Education, 18(2), 125-142.

Fay, B. (2006). Filsafat Ilmu Sosial Kontemporer. Yogyakarta: Jendela.

Herman, R. D. K. (2016). Traditional knowledge in a time of crisis: climate change, culture and communication. Sustainability Science, 11(1), 163-176.

Jati, W. R. (2013). Kearifan Lokal sebagai Resolusi Konflik Keagamaan. Walisongo: Jurnal Penelitian Sosial Keagamaan, 21(2), 393-416. 
Lubis, A. Y. (2006). Dekontruksi Epistemologi Modern, Dari Posmodernisme Teori Kritis Poskolonialisme Hingga Cultur Science. Jakarta: Pustaka Indonesia Satu.

Miles, M. B., \& Huberman, A. M. (1992). Analisis data kualitatif. Jakarta: UI Press.

Mudana, I. W., \& Rahman, A. (2017). The Negative Stigma Against the Bajo Tribe and its Impact on Local Culture: Study of the Bajo Tribe in Bungin Village of South Konawe. Asian Culture and History, 9(2), 90-95.

Mungmachon, M. R. (2012). Knowledge and local wisdom: community treasure. International Journal of Humanities and Social Science, 2(13), 174-181.

Naim, N., \& Sauqi, A. (2008). Pendidikan multikultural: konsep dan aplikasi. Ar-Ruzz Media.

Pettalongi, S. S. (2013). Islam dan Pendidikan Humanis dalam Resolusi Konflik Sosial. Jurnal Cakrawala Pendidikan, (2), 1-11.

Pranowo, B. (1998). Islam Faktual Antara tradisi dan Relasi Kuasa. Yogyakarta: Adicita Karya Nusa.

Taena, L., Sailan, Z., Nalefo, L., Basri, A., Laepe, A., Samsul, S., ... \& Kuasa, W. (2016). The Cultural Tradition of "Falia" in Preserving Forest by Munanese Ethnic. Journal of Sustainable Development, 9(5), 200-206.

Yeh, C. J., Ma, P. W., Madan-Bahel, A., Hunter, C. D., Jung, S., Kim, A. B., ... \& Sasaki, K. (2005). The cultural negotiations of Korean immigrant youth. Journal of Counseling \& Development, 83(2), 172-182.

Zacot, F. R., Muljono-Larue, F., \& Pranoto, I. B. (2008). Orang Bajo, suku pengembara laut: pengalaman seorang Antropolog. Kepustakaan Populer Gramedia (KPG).

\section{Copyrights}

Copyright for this article is retained by the author(s), with first publication rights granted to the journal.

This is an open-access article distributed under the terms and conditions of the Creative Commons Attribution license (http://creativecommons.org/licenses/by/4.0/). 